УДК $82-31(141.32)=111$

\title{
Modern Existentialist Novel: Code-Mixing
}

\author{
Galina I. Lushnikova \\ and Tatiana Iu. Osadchaia* \\ V.I. Vernadsky Crimean Federal University \\ 4 Vernadskogo, Simferopol, Republic of Crimea, \\ 295007, Russia
}

Received 14.11.2017, received in revised form 18.12.2017, accepted 15.01.2018

The paper focuses on the phenomenon of code-mixing, i.e. functioning of the units of various textual systems within the frame of one text, which is realized in modern existentialist novels and proves to be one of the main tendencies of postmodern literature. The subject-matter of the analysis is the thematic, conceptual, genre levels and the level of literary discourse strategies of the artistic narrative. The code-mixing demonstrates specific qualities at each of the levels: a great number of different themes and messages discussed in literary works; multiculturalism; genre contamination, developing of new genres and subgenres; intertextuality of new types and forms, interrelation of elements inherent to various discourses and semiotic systems. The authors of the article conclude that reading and analyzing fiction of code-mixed nature imply such methodological tactics as identifying markers of different codes, defining their functions and resulting effect of interaction within a particular novel. These steps contribute to more adequate understanding, interpreting and decoding of elaborate existentialist texts.

Keywords: existentialist novel, postmodernism, artistic narrative, code-mixing, literary discourse strategies, multiculturalism, intertextuality.

DOI: 10.17516/1997-1370-0210.

Research area: philology.

\section{Introduction}

The development of literary process at the modern stage is characterized by coexistence in one and the same work of literature of different (and very often contradictory) trends and esthetic features. The boundary between high and mass literature is becoming less and less distinct. Literary texts combine realistic traditions, modernistic experiments, and postmodern tendencies, though the realistic paradigm appears to be a prevailing one. According to a prominent researcher of modern British Literature
N. Bentley, "the postmodern, then, operates at (at least) two distinct and interconnected levels in historical terms. It signals a style of writing that supersedes $\langle\ldots>$ whilst at the same time employing a philosophical outlook that rejects many of the tenets of modernity $<\ldots$.. " (Bentley, 2008: 32).

Realistic methods in modern works of literature nowadays is a typical and widely spread tendency, that is why literary critics have all grounds to declare the originating of such a literary trend as New Realism. New

(C) Siberian Federal University. All rights reserved

* Corresponding author E-mail address: lushgal@mail.ru; osadchaya_ta@mail.ru 
Realism has some specific characteristics. First of all, modern writers apply a whole arsenal of postmodern means aiming at deep penetration into the inner world of their main characters. On the second hand, modern writers highlight rather routine circumstances of ordinary people's life whose images are typical for a definite society in a definite period of time (our times) than some global social and political issues, vital for the mankind. Thirdly, modern writers do not place themselves superior to their personages and readers; a modern writer is an exemplary representative of his or her epoch who confronts challenges of modern life and solves existential problems. As a consequence, in contemporary works of literature a mode of sympathy and confidentiality is dominating. Fourthly, the main ethic issue of New Realism is the value of life in all its diversity; modern writers declare the cult of life as it is (Kaznacheyev, 2011; Khlybova, 2010).

Within the frame of this paradigm the main tendency in modern literature is considered to be code-mixing which is realized at different textual levels: thematic, conceptual, the level of genre, composition, literary discourse strategies, functional styles, and narration. As a result, methodology and methods of literary and linguistic analyses of each work of literature nowadays should involve such steps as detecting and defining specific functional features of different systems of explication, investigating units belonging to different codes, assessing the character and type of their interaction and interinfluence, finding out their common and contrasted elements, the points of attraction and repulsion. As is stated by A. Esin, "while analyzing the text of literature a prominent and special attention should be paid not to the differentiation of various features (it is also necessary but at the first preliminary stage of analysis), but to their synthesis within one unit which may be called an artistic world" (Esin, 2015: 219-220).

The main force which is activated in a modern work of literature is the force of attraction when the text attracts and accumulates specific characteristics of different literary trends, elements of different discourses and semiotic systems, basic laws of various genres and functional styles. Composition and structure of the modern text appear to be amorphous systems, the so called systems of fuzzy sets.

The analysis proves the modern existentialist novel to demonstrate all the above mentioned features with varying degrees of intensity.

\section{Statement of the problem}

A modern existentialist writer follows and develops the traditions of modernistic philosophic prose and at the same time uses experimental postmodern means and instrumentality. None of the novels of this type can be regarded as purely existentialist. Comprehension and conceptualization of global problems of the modern world are the main grounds which allow us to classify them as belonging to this genre.

As is known such artistic trend as "beatniks" in the USA was based on the philosophy of existentialism. The brightest manifestation of the beatnik's ideas is presented in the J. Kerouac's novel The Town and the City. J. Kerouac discovered a spontaneous method of narration i.e. a narration reflecting the stream of conscience when the narrator's thoughts are depicted exactly in the same way and sequence as they come to his or her mind. In the novels written by such writers as Th. Wilder, N.K. Mailer, S. Bellow, W. Styron, J.I. Murdoch, M. Spark and some others there can be traced various interpretations of the role of an individual in a modern world. Moral and ethical pursuits, attempts to find out possible ways of self-identification were in the focus of attention of the postwar literature in America, namely in 
the novels by J. Updike, N. Mailer, S. Bellow, J.D. Salinger, W. Styron, Ph. Roth. All these and some other works of literature appeared to be a foundation which brought to life the modern existentialist novel.

An existentialist novel of our times can be characterized by the following intentions of a writer:

- to demonstrate the crisis of civilization and the wreckage of existing cultural values;

- to prove the futility of a person's striving to overcome the tragedy of his through a radical change of his or her world outlook and attitudes;

- to create an image of a character who for one reason or another "is thrown away" from the community and finds himself completely alone in the hostile environment (Alieva, 2011).

In this article the modern existentialist novel is presented as a piece of artistic work which corresponds to cultural and intellectual needs and tastes of a modern reader, as a special genre comprising almost all tendencies, discourses, literary and linguistic means of modern literature on the whole.

\section{Methods}

The basic research methods applied in this article are the following: general method of literary analysis, methods of decoding stylistics, and some principles of cognitive, conceptual and discourse analysis. These methods help analyze the main issues of postmodern trend in literature, genre peculiarities and such literary discourse strategies as psychological insight, multiculturalism, intertextuality. We proceed from the assumption that the phenomenon of code-mixing in the modern existentialist novel is actualized at all textual levels: thematic, conceptual, genre, stylistic, narrative, at the level of literary discourse strategies and others. The investigation of modern existentialist novels written in English proves code-mixing to be the most expressive and at the same time the most complicated and multifunctional at thematic, conceptual, genre levels and at the level of discourse strategies. The latter conclusion conditioned the framework of our investigation and as a consequence - the subject matter of this article.

\section{Discussion}

\section{Thematic level}

The investigation of the thematic level of most prominent modern existentialist novels written in English demonstrates a great variety of issues discussed on the pages of one and the same novel. It's a difficult and sometimes even impossible task to specify the leading message / problem / idea suggested by the author. It might be equally difficult to verbalize the subject matter / topic the author highlights. Thematic, esthetic and conceptual mixing in modern existentialist novels can be illustrated by some examples.

Novels by an American writer D. DeLillo are devoted to a great number of problems a person confronts with in his / her attempts to find out and comprehend the meaning of his or her life. All D. DeLillo's novels deal with a crucial idea of a human being's vulnerability in a modern world where every new day brings a lot of new and unexpected perils. Using a metaphor, we may state that his novels determine a diagnosis to a modern society. The author's main goal is to warn the mankind, to suggest some strategies and ways for its survival. D. DeLillo casts serious doubt on prospering of the American society, which to his mind is in fact a mere simulation of reality.

Literary critics find much in common between the ideas developed by D. DeLillo in his novels and those of a French postmodern philosopher J. Baudrillard. According to the philosopher a modern epoch is one of hyperreality, where the realm of the hyperreal come to control thought and behavior. Hyperreality consists of various 
simulacra (simulations of reality), i.e. fictional images of different reality fragments. As is stated by J. Baudrillard, very often hyperreality substitutes reality, it is an environment that totally shapes individuals' perception of reality and themselves. Thus hyperreality presents the situation in which phenomena of truth, adequacy, and reality cease to be perceived as ontologically grounded and instead are perceived as symbolic ones (Baudrillard, 2015).

In his novels D. DeLillo creates apocalyptic pictures of hyperreality. Under any circumstances his personages do their best to comprehend the world they live in. The main characters of the novel White Noise are concerned and preoccupied with fear of death and each of them does his or her best to overcome it. The word combination of the title - white noise - on the one hand, denotes the stream of information pouring daily on a man from different sources; on the other hand, white noise symbolizes permanent anxiety thoughts, speculations and talks about death used as a background against which all the events of the novel take place.

D. DeLillo creates various pictures of simulacra's explication in different spheres of life; his personages become victims of their own distorted perception of reality. This is reflected in the following novels: Libra presents the author's version of J. Kennedy's assassination, Falling Man is devoted to the catastrophe of 09.11, Cosmopolis describes personal crisis and despair of a protagonist who can hardly survive in the environment of hyperreality, Zero $K$ examines a fantastic idea of cryofreezing of people wishing to prolong their lives.

Modern existentialist novels focus on a great variety of essential issues, among them are the following: fragility and vulnerability of a man in a present-day hostile world, thanatophobia, an individual's experience of traumatic (and very often destructive) interrelation with an adverse environment, personal tragedies and attempts undertaken by a person to confront and overcome them, to find his or her own strategy for surviving in social medium. These themes are brightly elaborated in the following novels: The Cement Garden, The Child in Time by I. McEwan, The Wasp Factory by I. Banks, The White Hotel by D.M. Thomas, Staring at the Sun, The Pregnant Widow by M. Amis, The World According to Garp by J. Irving, Therapy by D. Lodge, Independence Day, Canada by R. Ford, The Thought Gang by T. Fischer and some others.

Not only personal but also collective experience (first of all connected with some historic events) may be the reason of tragic emotional upheaval of characters. The writers dealing with this subject matter develop themes of decay and disorder of modern civilization, impossibility to restore traditional values after all the tragic events happened in the $20^{\text {th }}$ century. Existentialist ideas may be also connected with an apocalyptic theme, which is mainly reflected through the atmosphere of fear and a catastrophe foreboding (a catastrophe both historic and cultural). What is more, the world's catastrophe is perceived by an individual as a personal experience, a personal tragedy. These motives are presented in the following novels: Time's Arrow or the Nature of the Offence by M. Amis, The Remains of the Day, The Unconsoled by $\mathrm{K}$. Ishiguro, What a Carve Up! by J. Coe, Waterland by G. Swift, Gravity's Rainbow by Th. Pynchon, Never Let Me Go by K. Ishiguro and others.

\section{Conceptual level}

Conceptual variety of modern existentialist novels is explained among other things by such a prominent feature of the present-day literature as multiculturalism. Modern works of literature often present social, political and other vital issues as viewed by representatives of different cultures and ethnicities within one society. Different 
writers interpret multiculturalism in their own ways conditioned by their national and cultural identity, the degree of their assimilation in a new environment, social status and so on. Such novels discuss different aspects of intercultural communication, cultural conflicts and bumps. As a rule, characters of these novels are shown in the process of reorientation and acculturation in a multicultural environment. The corpus of such novels offer valuable data for cognitive study, comparative analysis of national concepts, for observing historic events, traditions, customs and realia of world cultures. At the linguistic level code-mixing finds expression in borrowings, cases of transcription or transliteration of nonequivalent lexis, and in foreign words denoting specific cultural notions or elements which cannot be adequately rendered into English.

The motives of ethnic identity preserving and racial conflicts appear to be one of the most important in modern British, American and South-African literature. Personages' identities belong to two or sometimes more cultures which inevitably affects the process of their selfidentification and self-expression. They face challenges of both adapting in a new society and preserving their ethnic roots (Karasik, 2009).

Writers who left their native countries take up the issues of immigration and acculturation. One of the brightest examples where these questions are discussed is the creative work by a Chinese American writer Amy Tan. Apart from an intriguing plot her novels The Joy Luck, The Hundred Secret Senses, The Kitchen God's Wife deal with the challenges the Chinese can face in the American culture which is radically new for them. The author gives a vivid picture of the two cultures, their peculiarities and, what is the most important, shows possible ways of adjustment to the new cultural environment. A. Tan underlines the age factor in immigrants' adaption and settling-in. In her books she shows three age groups - people of the older generation who joined their children in immigration or had to leave China for America under definite political, social or personal circumstances; middleaged people who immigrated to America according to their own wish and inclinations; children of the immigrants who were born in America and do not know the country of their origin. Consequently, their perception of native and new cultures is not the same, more than that, their attitude towards the events and people described in the novels is quite diverse.

There are many interesting statements concerning key concepts of American and Chinese cultures in A. Tan's novels. As words in the two languages differ by their semantic volume there can occur redundancy or insufficiency of linguistic forms of one and the same concept in English and Chinese. For example, there may be traced some discrepancy between two interpretations of the concept fate. This concept reflects the contradiction between eternity of the world and unpredictability of human life. The following passage from the novel The Kitchen God's Wife illustrates the difference in views of an American man and a Chinese woman on the questions of destination, fate, inevitability:

How lucky we were that fate brought us together. But your father did not think it was fate, at least not the Chinese idea of ming yuan.

"Fate", he told me, "is somebody else deciding your life for you. Our love was greater than that". And here he used the American word "destiny", something that could not be prevented (Tan, 1991: 399).

The meanings of one and the same word interpreted from the viewpoint of different cultures do not always coincide. In Eastern cultures a higher force is considered to dominate a human, an individual's fate is supposed to be inevitably predetermined. According to the American world view as opposed to that of Chinese, people are creators of their own destiny, 
they are challenged to become responsible decision-makers. The American culture does not deny the existence of higher forces, divine will and consciousness but it also states that people can be influenced by those forces only if they refuse to be creators of their destiny. In English this concept is expressed by the word fate which means somebody else deciding your life for you. The meaning of the Chinese word ming yuan is expressed in English with the help of several words but each of them only partially renders the meaning of the Chinese ming yuan: fate, destiny, doom (Korneeva, 2009: 144-156).

The novel I am Not Sidney Poitier by P. Everett is characterized by almost all the modern literary traits. It highlights the theme of self-identification of an individual which appears to be topical for American literature of the last decade. The names of a protagonist and some other personages are those of real well-known persons which creates additional connotations to an imagery of the novel. The main attributes of the narration are irony and satire which sometimes acquire grotesque forms. The author parodies models and clichés used in American literature for delineation of racial discrimination of the Afro-Americans (Shchepacheva, 2013).

The novel Disgrace by South African writer J.M. Coetzee is the combination of basic traits of existentialist and academic novels. At the same time, it deals with the description of postcolonial realia. Its plot is rather typical for academic novels: a professor-student love affair resulting in the wreckage of his professional career. However, the novel Disgrace has some specific national colouring as it tells the reader about internal colonization, oppression of racial minorities (in a new postcolonial reality of the Republic of South Africa racial minorities are representatives of the white race), and the way of life in rural areas. The author speculates about the place of an individual in a society where irreconcilable worlds and discourses are forced to coexist, about an individual's attempts to reclaim his own self-esteem under social pressure of laws, moral obligations and ideological rules and norms. Describing the situation of disgrace in which the protagonist eventually finds himself the author raises his main question: what does the notion of grace can mean for a person?

\section{Genre level}

To identify more or less exactly the genre of a modern novel can often be a difficult task. We defined the genre under discussion as the existentialist novel however almost all the novels we had chosen for investigation prove to have characteristics of both this genre and some other genre or genres which sometimes may considerably differ from each other.

For example, an existentialist novel The Mind Parasites by C. Wilson is characterized by a fantastic plot and elements of dystopia. Basing his novel on the philosophical idea of the collective unconscious mind common to the mankind as a whole the author depicts that mind as the ocean overcrowded by alien and hostile elements. C. Wilson narrates about these mysterious antagonistic creatures that penetrate into human brain, interfere with its creative activity and self-development and sometimes may even drive a person to suicide. These creatures symbolize inertia, weakness, desire for comfort; they prevent individuals from realizing the full potential of their abilities, from opening their mind to new ideas. This is conveyed in the following extracts:

Mind is not really 'inside' us in the same sense that our intestines are. Our individuality is a kind of eddy in the sea of mind, a reflection of the total identity of the universal humanity.

Man is a continent, but his conscious mind is no larger than a back garden...man consists almost entirely of unrealized potentials. 
One of man's deepest habits is keeping alert for dangers and difficulties, refusing to allow himself to explore his own mind because he daren't take his eyes off the world around him (Wilson, 2015: 98-99).

Thus the author believes in high destiny and almost infinite potentials of Man. He declares self-understanding and personal responsibility for decisions to be the main tasks of any individual on Earth (Alieva, 2011).

The next example is P. Auster's The New York Trilogy (City of Glass, Ghosts, The Locked Room). The author exploits a genre form of a detective novel to present the drama of loneliness, depersonalization, ambiguity, leveling of personality in a mega metropolis. He tells the reader of an individual's pursuit to preserve his or her integrity, to understand his or her destination. The three novels of the trilogy contain different stories and can be read as separate works of literature. What they all have in common is the author's interpretation of the heroes and events described: the events are presented as if they happen for no particular reason (Karslieva, 2011: 113). The basic message of the trilogy is the following: the process of an individual's self-identification can be rather complicated and painful. The novels of the trilogy may be compared to a multidimensional labyrinth which consists of endless tunnels made of glass or mirrors that constantly change the personages' reflections / images. As a result, the characters can hardly define their own identity and differentiate themselves from their own reflections or counterparts.

Other P. Auster's novels are devoted to the same philosophical problem of Man's striving to overcome loneliness, isolation and aloofness from society which is inherent in the human civilization today. His novel In the Country of Last Things is a dystopia or, to be more exact, a post-apocalyptic novel; the books Moon Palace and Leviathan are existentialist novels which accentuate an individual, as opposed to community, consider possible ways of surviving of America's national idea; Sunset Park is an intertextual novel with elements of a dystopia which presents the author's speculations concerning the future of America.

The novel The Rachel Papers by an American writer M. Amis is of great interest mainly because its genre of a novel-confession, a coming-of-age novel is used for parodying existentialist issues. The polyphonic discourse of the novel includes such rhetorical posture as confession which is manifested in the first-person narration and passages of self-reflection. The effects of parody and irony can be traced in the main character's presentation: he is doing his best to follow the best examples of classical literary works, to use basic motives of most existentialist novels (e.g. he meditates about 'anxieties' that constantly torture him - different personal phobias; imperfection and finality of individual's existence on earth; fragility and gradual decay of the world), he refers to philosophical texts, novels and romantic poems by W. Blake and J. Keats, uses different kinds of allusions (Dzhumailo, 2012).

J. Barnes in his novel The Sense of an Ending explores an individual's search for meaning and purpose of life. This question comes back to the A. Camus's existentialist philosophy. There are a lot of allusions to A. Camus's The Myth of Sisyphus (Le Mythe de Sisyphe) in this novel: the author suggests its ironic interpretation and argues its philosophical statements. The novel is characterized by elements of detective fiction as the protagonist conducts his own investigation of his childhood friend Adrian's suicide motives. The narration is full of profound philosophical speculations: by reading Adrian's diary, scrutinizing his existentialist views, comparing them with those of his own, Tony Webster tries to draw a boundary between common sense and 
insanity, tries to resolve a contradiction between finality and absurdity of human existence on the one hand, and absolute values of human life and freedom, on the other (Sysoeva, 2015).

The novels Amsterdam and Saturday by I. McEwan belong to both existentialist and psychological genres. The author focuses his attention on life choices and emotional conditions of his characters. Depicting the predicaments they found themselves in the author meditates about the criteria and boundaries of an individual's normal mental state and adequate social behavior. The author puts his characters into critical borderline situations which cause feelings of both existential fear and urgent desire to bring their emotional state and clarity of thought into balance, to reevaluate their own lives. The motive of transforming / preserving the inner psychological world of individual under critical circumstances can be traced in both I. McEwan's novels.

A vivid example of a novel combining several genres within the existential framework is a novel Purity by J. Franzen. The heroine who has a speaking name Purity solves different self-identity problems: she tries to discover her father's secret and trace her family roots, to identify and prioritize her values, to find her place in professional and personal life. Demonstrating the heroine's difficult search for identity the author addresses the most important challenges of today: almost totalitarian power of internet and social networks, ideological inheritance of the past (one of the characters was born and brought up in German Democratic Republic), a great number of political and social movements fighting for better life as opposed to almost absolute absence of ideals, purity and aspiration for sinlessness in a modern society. The novel Purity can be called a detective, family, love story, a socio-psychological, historical and educational novel. It contains a great number of intertextual markers (e.g. allusions to the Ch. Dickens's novel Big Expectations), intricate metaphors, irony, and satire which are aimed at conveying the spirit of the time, presenting psychological portraits, creating a panoramic representation of a rapidly changing world and its values. Besides, the author underlines universal and eternal character of the questions discussed.

One of the brightest examples of both existentialist and academic novel is D. Lodge's Campus Trilogy. The plot of the first novel of the trilogy Changing Places: A Tale of Two Campuses centers round academic interchange between British and American universities. The relationship between two fictional universities is presented as a meeting of two opposite worlds and the main characters - two professors - appear to be polar opposites of each other. The author exploits various postmodern means: he ironically uses allusions and reminiscences, parodies a Victorian novel by Ch. Dickens A Tale of Two Cities. This parody is marked by the obvious similarity of the books' titles: A Tale of Two Cities and A Tale of Two Campuses. D. Lodge mocks some $20^{\text {th }}$ century realia and principles of academic systems in Britain and America. According to the author, American educational system reconstructs and even turns upside down the traditional academic principles of the British system (Novikova, 2016).

One more example illustrating the combination of existentialist and academic genres in one work of literature is a novel The Marriage Plot by an American writer J. Eugenides. The heroine of the book Madeleine majors in English and her senior thesis is devoted to the marriage plot in the greatest English novels. The title of her paper is almost the same as that of the novel A Marriage Plot in Literature. And it is not an occasional coincidence as the heroine investigates the theme of happiness in marriage both in theory and in her love life. 
Having married Leonard Madeleine faced in practice the eternal questions of life: what is the purpose of marriage, what is the secret for a happy marriage, are those who love able to overcome different life predicaments? Unfortunately, in real life matrimonial plots do not always have happy endings. The author backs up this sad conclusion with the words of an English Victorian writer A. Trollope: There is no happiness in love, except at the end of an English novel. The heroine uses this quote with a slight alteration as an epigraph to her final paper: The way of true love never works out except at the end of an English novel (Eugenides, 2012: 19).

The novel Stoner by an American writer J. Williams also combines characteristics of several genres: it's an academic, psychological and, to a great extent, existentialist novel. The author tells us a story of a common American by the name of Stoner who comes from a family of modest means. The protagonist is trying to find his personal destination both in professional careers of teaching and writing and in his private life.

The novel delineates the whole life of this ordinary man - his personal development, changes in his character under different circumstances, feelings and desires which imprinted his perception of the world. Such a deep insight into his world gives the reader an opportunity to observe certain regularities in person's life, to meditate about the purpose of his existence in different capacities: professional career, the sphere of feelings and affections, selfidentification. Reflections on the protagonist's life provoke questions which the reader puts to him or herself: do I live a good life, is this exactly what I dreamt of, do I really need all the things I have and do, isn't it late to change my life. Not by chance Anna Gavalda, who translated the novel into French, wrote: "Stoner is me". We can also add: "Stoner is each of us".

\section{Literary discourse strategy level}

Modern fiction manifests some more patterns of code-mixing and code-interrelation. They are various literary discourse strategies, such as modality, informative aspect of the text, intertextuality and some others. In the existentialist novel the most common discourse strategy is intertextuality, which implies interrelation of textual, semiotic and discourse codes.

One of the brightest examples of semiotic interrelation can be traced in the novel The Goldfinch by an American writer D. Tartt. The central element of the plot, composition, and characters' conveying which emerges in the novel in a number of ways is ekphrasis. The term ekphrasis refers to a literary (rhetorical) device used for description of a work of art (painting, architecture, etc.), to verbal description of nonverbal images, i.e. a double description, an image of the image (Gorodnitskii, 2014: 13). The plot of The Goldfinch centers round a masterpiece of painting 'The Goldfinch' by a Dutch artist Carel Fabritius. The author presents the image of the painting in turning points of the story: Theo, the main character, repeatedly restores it in his imagination. The painting works both as a metaphor - it becomes a symbol of eternal beauty, and a reason for Theo's worldview changes. Theo states this point in the following way:

The painting was the secret that raised me above the surface of life and enabled me to know who I am (Tartt, 2014: 484).

Ekphrasis enables the author to investigate the role of art in the world in general and in personal development in particular. The main character's meeting with the painting appears to be a turning point in his life: he gradually discovers the values which make life worth living.

Admiration for the painting led Theo to existential reflections on the meaning and meaninglessness of being. The author declares 
that art can overcome cruelty of life and even destructive force of time as it speaks about eternal values. The protagonist may be regarded the author's mouthpiece:

For if disaster and oblivion have followed this painting down through time - so too has love. Insofar as it is immortal (and it is) I have a small, bright, immutable part in that immortality. It exists; and it keeps on existing. And I add my own love to the history of people who have loved beautiful things, and looked out for them, and pulled them from the fire, and sought them when they were lost, and tried to preserve them and save them while passing them along literally from hand to hand, singing out brilliantly from the wreck of time to the next generation of lovers, and the next (Tartt, 2014: 488).

I. McEwan uses elements of different discourses extensively in his works. The novel Saturday is full of terms pertaining to medical, sport and musical discourses, the novel Amsterdam is characterized by inclusions of musical, political and journalistic discourses. This discourse mixing makes characters' worldview, cultural level and hobbies more realistic (Bezborodnikova, 2016).

Intertextuality in modern existentialist fiction reveals itself in new forms, one of which is so called ambivalent intertextuality. In some literary works under investigation there can be traced interrelation of two opposite forces the force of negation and the force of assertion. Thus the ambivalence is based on the ambiguity model where similarity and dissimilarity of an item are combined. Ambivalence organizes the person's movement of thought which bases on synthesis of perception where mutually exclusive opposites penetrate into each other and push away from each other (Riabova, 2014: 753). Examples of the intertextual ambivalence can be found in A. Croft's fiction. The subtitles of some of his works serve as negative references to the works mentioned by the author: probably not by Victor Pelyevin; not from Boris Pasternak's diary; certainly not by Sergei Lukianenko and the like. This formal negation contradicts the plots and the contents of the works which in fact present either pastiche or parody of the works of fiction mentioned in the subtitles.

Intertextual links, their functions and role in modern existentialist novels demonstrate a wide range of variety.

In the novel Nice Work by D. Lodge intertextuality is realized in a number of ways: the book's theme; citations, allusions, reminiscences, literary associations; rhetoric means of collage and pastiche. Intertextuality in this novel is multifunctional: Victorian novels play the role of a cultural background, a device for personages' characterization and a means of meta-literal play with a reader (Tolstykh, 2008).

The method of artistic identification, typical for academic prose, is brilliantly realized in the novel Blue Angel by F. Prose. The main character, being an intellectual in the sphere of arts, within the frame of his professional activity constantly deals with the works of culture. Such immersion in diverse cultural codes makes him gradually reconsider them which in its turn leads him to ironic self-reflection. In search for his true self, his place in life the main character identifies himself or discovers close relations with one or more literary characters of classic works of literature. Secondary cultural codes create a special atmosphere of the novel's reality, and thus realize the author's artistic conception. The reader is supposed to be engaged in the dialogue with the texts of classical literature and with the text of the novel itself and reconstruct his or her own meanings. This approach creates a vast field of interpretation for the reader.

Stylistics of the novel White Noise by D. DeLillo resembles the visual imagery of a 
movie or TV show as it consists of completed episodes, elaborate scenes and dialogues. The narration is penetrated with random TV programs, advertisements and blitz of commercials which become part of personages' dialogues and the stream of their thoughts.

Nice Work, the third novel of Campus Trilogy by D. Lodge, is full of allusions to English Victorian fiction, namely to such novels as North and South by E. Gaskell, Little Dorrit and Hard Times by Ch. Dickens, Jane Eyre and Shirley by Ch. Bronte, Wuthering Heights by E. Bronte, Alton Locke by Ch. Kingsley and some others. These allusions create a special colouring of life and professional activity of the heroine. (Novikova, 2016).

The novel Invisible by $\mathrm{P}$. Auster is a metafiction (fiction about fiction, a selfconscious novel, a novel which emphasizes its own imaginary character) which combines memoirs, diary notes and fiction itself. This novel is devoted to the theme of collision between an innocent character and the world of evil and absurdity (Bronich, 2015: 46). The composition of the novel is rather complicated: each of its four parts has a special narrator; the novel is written in the form of memoirs, letters, incomplete drafts of a novel and critical notes on them, detailed descriptions of the events. The reader has to correlate different narration modes, to differentiate true-to-fact and fictional stories, documental and fictional event presentations; the reader is supposed to exert more efforts for understanding and interpreting the novel. The title of the novel Invisible is an allusion to the work of a French phenomenological philosopher M. Merleau-Ponty The Visible and the Invisible which deals with the notion of truth (the invisible). His theory is based on the assumption that a human being is involved in the world through the language, speech, and linguistic experience. According to P. Auster it is storytelling or verbal self-expression of individual that makes it possible to percept and comprehend the world (Bronich, 2015).

\section{Conclusion}

Thus the existentialist novel is a genre wherein the author using the whole set of postmodern means and devices addresses universal themes and issues on the meaning of human existence: the burden of loneliness and fear of death, alienation of an individual from society, possible ways of survival under tragic circumstances, striving for purpose in life in the gradually destructing civilization which suffers from an overwhelming influence of simulacra and false ideas.

The analysis of a number of modern existentialist novels written in English proves that almost all their textual levels demonstrate code-mixing and code-switching, and manifest various and complicated interrelations between the elements pertaining to different discourses. As is known defining the code system (a functional style, genre, literary trend and so on) of the work of literature makes it easier to percept, interpret, and adequately decode the text and thus this technique determines the forecasting activity of the reader. The process of reading texts of code-mixed nature is time-consuming and effort-intensive as it requires much more reader's attention, wider thesaurus and philological background, greater intellectual efforts. While reading such kind of literature the readers are not only to find out the markers of different codes, but also to identify their functions and the effect achieved by their interrelations. Code-aware reading helps the readers comprehend and enjoy a polyphonic melody of the texts which take advantage of code and system mixing. Such code-aware reading can become a subject of further studies in the field. 


\section{References}

Alieva, Kh.I. (2011). Osobennosti zhanra ekzistentsialistskogo romana v angliiskoi literature [Peculiarities of a genre of existentialistic novel in English literature], In Vestnik Permskogo universiteta. Filosofiia. Psikhologiia. Sotsiologiia [Bulletin of Perm University. Philosophy. Psychology. Sociology], 2 (6), 61-64.

Baudrillard, J. (2015). Simuliakry $i$ simuliatsii $=$ Simulacra et simulation [Simulacra and simulation $=$ Simulacra et simulation]. Moscow, Ripol-klassik, $240 \mathrm{p}$.

Bentley, N. (2008). Contemporary British Fiction: Edinburgh Critical Guides. Edinburgh, Edinburgh University Press, 264 p.

Bezborodnikova, E.V. (2016). Interdiskursivnye vkliucheniia v romane I. Mak'iuena «Subbota» [Interdicursive inclusions in Ian McEwan's novel 'Saturday'], In Ogarev-online, 17, available at: http:// journal.mrsu.ru/arts/interdiskursivnye-vklyucheniya-v-romane-i-makyuena-subbota (accessed 17 October 2017).

Bronich, M.K. (2015). Pravda i vymysel v romane Pola Ostera «Nevidimoe»: amerikanskaia i evropeiskaia traditsii [Truth and fiction in Paul Auster's novel Invisible: The American and European literary tradition], In Vestnik Nizhegorodskogo universiteta im. N. I. Lobachevskogo [Bulletin of the Nizhny Novgorod University], 2 (2), 45-50.

Dzhumailo, O.A. (2012). Ekzistentsial'nyi opyt i granitsy literaturnoi samorefleksii v romane M. Emisa «Zapiski o Reichel» [Existential experience and the limits of literary self-reflectivity in Martin Amis's novel "The Rachel Papers"], In Problemy filologii, kul'turologii $i$ iskusstvoznaniia [Problems of Philology, Culturology and Art History], 3, 233-238.

Esin, A.B. (2015). Printsipy i priemy analiza literaturnogo proizvedeniia [Principles and methods of the literary work analysis]. Moscow, FLINTA: Nauka, 248 p.

Eugenides, J. (2012). The Marriage Plot. New York, Picador, 416 p.

Gorodnitskii, E.A. (2014). Eksfrasis v strukture literaturnogo proizvedeniia: izobrazitel'naia i narrativnaia funktsii [Ekphrasis in the structure of a literary work: descriptive and narrative functions], In Visnik Dnipropetrovs'kogo universitetu imeni Al'freda Nobelia. Seriia «Filologichni nauki» [Bulletin of Dnipropetrovsk Alfred Nobel University. Philology], 2 (8), 13-18.

Karasik, O.B. (2009). K voprosu o mul'tikul'turalizme v sovremennoi literature SShA [Discussing multicultural aspects of the modern American literature], In Vestnik Piatigorskogo gosudarstvennogo lingvisticheskogo universiteta [Bulletin of Pyatigorsk State Linguistic university], 4, 218-221.

Karslieva, D.K. (2011). Svoeobrazie traditsionnoi formy v «N'iu-Iorkskoi trilogii» Pola Ostera [The peculiarity of the traditional form in "The New-York Trilogy" by Paul Auster], In Vestnik VolGU [Bulletin of Volzhskiy State University], Ser. 8, 10, 109-114.

Kaznacheyev, S.M. (2011). Novyi realizm: ocherednoe vozrozhdenie metoda [New Realism: The Next Revival of a Method], In Gumanitarnyi vector [Humanitarian vector], 4 (28), 91-95.

Khlybova, N.A. (2010). Postmodernisticheskii kontsept v literature i literaturovedenii [The postmodern concept in literature and theory of literature], In Kul'tura narodov Prichernomor'ia [Culture of the peoples of the Black Sea], 196-1, 80-85.

Korneeva, T.A. (2009). Iazykovye realizatsii osobennostei natsional'noi kartiny mira $v$ khudozhestvennom tekste (na materiale romanov E. Tan) [Linguistic implementation of the national picture of the world in a literary work (on the novels by A. Tan)]. Kemerovo, $192 \mathrm{p}$. 
Novikova, V.Iu. (2016). «Universitetskaia trilogiia» D. Lodzha v rusle postmodernistskoi intertekstual'noi traditsii [“Campus Trilogy" by D. Lodge in the postmodern intertextual tradition], In Aktual'nye problemy gumanitarnykh i estestvennykh nauk [Topical issues of humanities and science], 9-2, 24-26.

Riabova, M.E. (2014). Razvitie predstavlenii ob ambivalentnosti v filosofii na rubezhe XX-XXI vekov [Evolution of ambivalence's concepts in philosophy at the turn of the $20^{\text {th }}$ and $21^{\text {st }}$ centuries], In Vestnik MGTU [Bulletin of Murmansk State Technical University], 17-4, 753-758.

Tan, A. (1991). The Kitchen God's Wife. New-York, Ivy Books, 532 p.

Shchepacheva, I.V. (2013). Obrazy real'nykh lichnostei v romanakh P. Everetta [Images of real personalities in P. Everett's novels], In Filologiia i kul'tura [Philology and culture], 1(31), 175-177.

Sysoeva, Iu.N. (2015). Formy khudozhestvennoi retseptsii filosofii A. Kamiu v romane Dzh. Barnsa «Predchuvstvie kontsa» [Forms of artistic reception of the philosophy of A. Camus in the novel by J. Barnes "The sense of an ending"], In Izvestiia Volgogradskogo gosudarstvennogo pedagogicheskogo universiteta [Bulletin of Volgograd State Pedagogical University], 8(103), 162-165.

Tartt, D. (2014). The Goldfinch. London, Abacus, 880 p.

Tolstykh, O.A. (2008). Angliiskii postmodernistskii roman kontsa 20 veka $i$ viktorianskaia literatura: intertekstual'nyi dialog (na materiale romanov A.S. Baietti D. Lodzha) [English postmodern novel of the late $20^{\text {th }}$ century and Victorian literature: intertextual dialog (on the novels by A.S. Byatt and D. Lodge)]. Moscow, $24 \mathrm{p}$.

Wilson, C. (2015). The Mind Parasites. New-York, Monkfish Book Publishing Company, 240 p.

\title{
Современный экзистенциалистский роман: взаимодействие кодов различных систем
}

\author{
Г.И. Лушникова, Т.Ю. Осадчая \\ Крымский федеральный университет \\ имени В.И. Вернадского \\ Россия, 295007, Республика Крым, \\ Симферополь, пр. Вернадского, 4
}

\begin{abstract}
Статья посвящена изучению такой ведущей тенденции современного англоязычного экзистенциалистского романа, как кодовое смешение - одновременное использование элементов, присущих разным текстовым системам. Предметом анализа послужили тематический, кониептуальный, жанровый и категориальный уровни художественного нарратива. Проведенное исследование позволило прийти к ряду теоретических и практических выводов: идейно-тематическая разнородность современного художественного произведения заключается в многоплановой и разносторонней проблематике; концептуальный уровень характеризуется мультикультурнымм подходом; жанровая специфика проявляется в сочетании двух или более жанров и возникновении новых жанров и поджанров; ведущими категориями текста литературы становятся интертекстуальность, интердискурсивность и интерсемиотичность. Авторы статьи считают, что чтение и анализ произведений, демонстрируюших кодовую контаминацию, предполагает обязательное выявление маркеров различных кодов, определение их функиий и результирующего эффекта их взаимодействия. Чтение, ориентированное
\end{abstract}


на изучение кодового смешения, способствует более адекватному пониманию и интерпретаиии сложного полифонического звучания современного экзистенциалистского романа.

Ключевые слова: экзистенциалистский роман, постмодернизм, художественный нарратив, кодовое смешение, категории текста, мультикультурализм, интертекстуальность.

Научная специальность: 10.00.00 - филологические науки. 